\title{
Ávísanir á punglyndislyf, róandi lyf og svefnlyf hjá ungu fólki fyrir og eftir bankahrun
}

\author{
Pversniðsrannsókn í Heilsugæslu höfuðborgarsvæðisins
}

Árni Arnarson ${ }^{1}$ læknanemi

Jón Steinar Jónsson ${ }^{1,2,3}$ æknir

Margrét Ólafía Tómasdóttir ${ }^{1,2} \mid æ k n i r$

Emil Lárus Sigurðsson ${ }^{1,2,3} \mid æ k n i r$

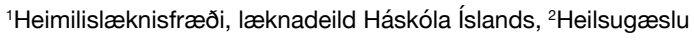
höfuðborgarsvæðisins, ${ }^{3}$ Próunarmiðstöð íslenskrar heilsugæslu.

Fyrirspurnum svarar Emil Lárus Sigurðsson, emilsig@hi.is

\section{Inngangur}

Haustið 2008 féllu íslensku bankarnir og í kjölfarið fylgdi efnahagskreppa á Íslandi. Henni fylgdu efnahagslegir erfiðleikar hjá mörgum, atvinnuleysi jókst og rétt tæplega helmingur íslenskra heimila taldi sig eiga í fjárhagsvandræðum. ${ }^{1,2}$ Rannsóknir um áhrif slíkrar kreppu á heilsu eru ekki samhljóma. ${ }^{3}$ Íslenskar rannsóknir sýndu að strax í kjölfar hrunsins urðu breytingar á komum á Hjartagátt en vikuna sem bankarnir féllu varð $41 \%$ aukning á komum kvenna miðað við vikurnar fjórar par á undan og tæplega 80\% aukning varð á komum vegna vísbendinga um kransæðasjúkdóma. Engin marktæk aukning varð á komum karla á Hjartagátt á sama tímabili. ${ }^{4}$ Í Evrópu og Norður-Ameríku hafa rannsóknir sýnt fram á aukna tíðni sjálfsvíga eftir efnahagshrun, meira hjá körlum en konum. ${ }^{5,6}$ Á Íslandi lækkaði hins vegar tíðni sjálfsvígstilrauna og sjálfskaða hjá báðum kynjum í kjölfar hrunsins. ${ }^{7}$

Рað er vel pekkt að lyfjanotkun hér á landi er meiri en á hinum Norðurlöndunum og árlegar skýrslur Norrænu heilbrigðistölfræðinefndarinnar (NOMESCO) um lyfjanotkun á Norðurlöndum sýna að notkun punglyndislyfja, róandi lyfja og svefnlyfja er hlutfallslega mest á Íslandi. ${ }^{8-10}$

Árið 2016 var hlutfallsleg notkun punglyndislyfja 143\% meiri á Íslandi en í Noregi og 43\% meiri en í Svípjóð.,11 Pá er notkun punglyndislyfja meiri hér á landi en í öllum öðrum OECD-ríkjum. ${ }^{12}$ Stærstur hluti peirra punglyndislyfja sem ávísað er á Íslandi tilheyrir flokki sértækra serótónín-endurupptökuhemla (SSRI) og stór hluti fjölgunar á ávísunum á punglyndislyf skýrist af fjölgun ávísana á pau lyf. ${ }^{913}$ Notendur SSRI-lyfja eru um 50-100\% fleiri hér á landi en á hinum Norðurlöndunum. ${ }^{14}$ Úttekt Embættis landlækn-

\section{Á G R I P}

\begin{abstract}
BAKGRUNNUR
Haustið 2008 var efnahagskreppa hér á landi og hafa rannsóknir sýnt fram á bæði fjárhagslegar og heilsutengdar afleiðingar. Einnig er vel pekkt að̃ lyfjanotkun hér á landi hefur veriơ meiri en á Norðurlöndunum og á pað̃ međal annars við um punglyndis-, róandi og svefnlyf. Tilgangur rannsóknarinnar var að kanna próun ávísana á ofangreind lyf í Heilsugæslu höfuðborgarsvæðisins á tímabilinu 2006-2016 hjá einstaklingum 18-35 ára.
\end{abstract}

\section{EFNIVIĐUR OG AĐFERĐIR}

Rannsóknin náđi til allra ávísana á punglyndis-, róandi og svefnlyf hjá 18-35 ára skjólstæđingum Heilsugæslu höfuðoborgarsvæðisins á tímabilinu 2006-2016. Fjöldi íbúa á höfuð̋borgarsvæðinu í aldurshópnum var um 55.000 á tímabilinu. Gögn voru fengin úr „Sögu“, rafrænu sjúkraskrárkerfi heilsugæslunnar, fyrir tæplega 23.000 einstaklinga.

\section{NIĐURSTÖĐUR}

Á rannsóknartímabilinu fjölgaði ávísuðum dagsskömmtum róandi lyfja að meðaltali um 3,0\% ( $<<0,001)$ milli ára, svefnlyfja um $1,6 \%$ $(p<0,001)$ og punglyndislyfja um 10,5\% ( $p<0,001)$. Frá 2008-2009 fjölgaði ávísuðum dagsskömmtum róandi lyfja um 22,7\% ( $p<0,001)$, par af um 12,9\% $(p<0,001)$ hjá konum og 39,5\% $(p<0,001)$ hjá körlum. Af peim körlum sem fengu ávísað róandi lyfjum árið 2009 höfðu 35\% peirra ekki fengið ávísað lyfjunum árið áđur. Frá 20062008 var að međaltali $13,6 \%(p<0,001)$ aukning á milli ára i útskrifuðum dagsskömmtum svefnlyfja, par af $24,4 \%(p<0,001)$ aukning hjá körlum og 7,8\% $(\mathrm{p}<0,001)$ hjá konum.

\section{ÁLYKTANIR}

Rannsóknin sýnir auknar ávísanir á svefnlyf og róandi lyf í aðdraganda efnahagshrunsins, sérstaklega til karla. Á sama tíma sést ekki samskonar aukning á ávísuðu magni punglyndislyfja sem bendir til pess að skammvirkum fljótvirkum lyfjum hafi verið ávísað í tengslum við erfiðar persónulegar aðstæður í kringum hrunið.

is á ávísanir á punglyndislyf frá 2012-2016 sýndi mikla fjölgun notenda. Yngri notendum fjölgaði mest á tímabilinu og í hópi 15-19 ára voru peir 62,2\% fleiri árið 2016 en árið 2012. Hlutfall notenda jókst með hækkandi aldri og var mest hjá eldra fólki. ${ }^{13}$ Önnur úttekt Embættis landlæknis á notkun punglyndislyfja benti til pess að auk pess sem notendum hafi fjölgað séu stærri skammtar gefnir eða einstaklingar noti lyfin lengur. ${ }^{15}$ Óljóst er hvort algengi punglyndis í almennu pýði hér á landi sé meira en annars staðar, en í yfirlitsgrein frá Embætti landlæknis kemur fram að samkvæmt erlendum rannsóknum sé algengið talið vera um $15 \%{ }^{14}$ 
Tafla I. Fjöldi einstaklinga, ávísana og DDD frá 2006 til 2016. Einstaklingar 18-35 ára sem fengu ávísað punglyndislyfjum, róandi lyfjum og svefnlyfjum hjá Heilsugæslu höfuðborgarsvæðisins á tímabilinu 2006-2016.

\begin{tabular}{|c|c|c|c|c|c|c|c|c|c|c|c|c|}
\hline & 2006 & 2007 & 2008 & 2009 & 2010 & 2011 & 2012 & 2013 & 2014 & 2015 & 2016 & $\begin{array}{l}\text { Breyting } \\
\text { frá 2006- } \\
2016 \text { [\%] }\end{array}$ \\
\hline \multicolumn{13}{|c|}{ Róandi lyf (N05B) } \\
\hline Einstaklingar & 946 & 1012 & 1137 & 1073 & 1120 & 1228 & 1331 & 1378 & 1389 & 1613 & 1654 & 74,8 \\
\hline Ávísanir & 2465 & 2821 & 3148 & 3298 & 3138 & 3183 & 3265 & 3365 & 3776 & 4099 & 4313 & 75,0 \\
\hline DDD & 40.642 & 46.449 & 50.341 & 60.077 & 55.598 & 51.839 & 53.850 & 52.303 & 61.339 & 62.303 & 68.549 & 68,7 \\
\hline \multicolumn{13}{|c|}{ Svefnlyf (N05C) } \\
\hline Einstaklingar & 1045 & 1074 & 1104 & 1127 & 1181 & 1188 & 1123 & 1066 & 990 & 1014 & 1038 & $-0,7$ \\
\hline Ávísanir & 3384 & 3896 & 4414 & 4291 & 4694 & 4473 & 4124 & 3908 & 3804 & 3856 & 3993 & 18,0 \\
\hline DDD & 79.520 & 96.165 & 111.475 & 109.686 & 119.020 & 112.534 & 106.309 & 112.950 & 113.045 & 113.230 & 119.554 & 50,3 \\
\hline \multicolumn{13}{|c|}{ Punglyndislyf (N06A) } \\
\hline Einstaklingar & 2866 & 3003 & 3006 & 2890 & 3080 & 3163 & 3470 & 4004 & 4292 & 4893 & 5355 & 86,8 \\
\hline Ávísanir & 12.501 & 13.494 & 13.881 & 10.342 & 9676 & 9774 & 10.487 & 12.546 & 13.605 & 15.746 & 17.666 & 41,3 \\
\hline DDD & 695.035 & 779.293 & 812.354 & 881.784 & 930.432 & 1.006 .774 & 1.110 .605 & 1.348 .337 & 1.480 .295 & 1.712 .854 & 1.977 .460 & 184,5 \\
\hline
\end{tabular}

Notkun róandi og kvíðastillandi lyfja er einnig hlutfallslega meiri hér á landi en í nágrannalöndum. ${ }^{9,16}$ Par sem lyfin eru ávanabindandi er ávísun og notkun peirra til langs tíma sérstakt viðfangsefni. Árin 2012 og 2013 fækkaði í fyrsta skipti frá pví skráning hófst einstaklingum sem fengu ávísað róandi lyfjum en ávísað magn hefur nokkurn veginn staðið í stað. Athygli vakti að fullorðnum einstaklingum sem fengu ávísað pessum lyfjum fækkaði en á móti fjölgaði börnum og ungmennum sem fengu ávísað lyfjunum. $^{17}$

Notkun svefnlyfja er, rétt eins og notkun punglyndislyfja og róandi lyfja, hlutfallslega meiri hér á landi en á hinum Norðurlöndunum. Árið 2016 var ávísað 68,4 DDD/1000 íbúa/dag hérlendis miðað við 49,7 í Svípjóð sem kom næst og 14,3 í Danmörku par sem notkunin var minnst.,18 Fleiri konur en karlar fá ávísað pessum lyfjum. Prátt fyrir pessa miklu notkun hafði dregið úr henni frá 2012-2014 um 5,2\% meðal karla og 5,5\% meðal kvenna. ${ }^{19}$ Mikil notkun svefnlyfja hér á landi miðað við hin Norðurlöndin er aðallega talin skýrast af fleiri notendum frekar en stærri lyfjaskömmtum. ${ }^{10}$ Pá hafa rannsóknir sýnt að algengi svefntruflana og notkun svefnlyfja eykst með hækkandi aldri. ${ }^{20}$

Tilgangur rannsóknarinnar var að kanna próun ávísana á punglyndislyf, róandi lyf og svefnlyf hjá skjólstæðingum Heilsugæslu höfuðborgarsvæðisins (HH) á aldrinum 18-35 ára frá árinu 2006, tæplega premur árum fyrir efnahagshrun, til og með ársins 2016.

\section{Efniviður og aðferðir}

Rannsóknin er lýsandi pversniðsrannsókn sem náði til 11 ára tímabils frá 1. janúar 2006 til 31. desember 2016. Skoðaðar voru ávísanir á punglyndislyf, róandi lyf og svefnlyf hjá HH til einstak- linga 18-35 ára en HH rekur 15 heilsugæslustöðvar á höfuðborgarsvæðinu og pjónustar yfir 55.000 einstaklinga á pessu aldursbili.

Upplýsinga var aflað úr rafrænu sjúkraskrárkerfi $\mathrm{HH}$, „Sögu“, og leitað að sjúklingum 18-35 ára sem höfðu fengið ávísað að minnsta kosti einu lyfi úr ATC-flokki punglyndis- (N06A), róandi (N05B) eða svefnlyfja (N05C). Í flokki punglyndislyfja eru 5 undirflokkar. Pær breytur sem notaðar voru við rannsóknina eru eftirfarandi fyrir hvern einstakling: aldur, kyn, árlegur fjöldi lyfjaávísana í hverjum flokki og undirflokki ofangreindra lyfja (8 breytur fyrir hvert ár), árlegur DDD (defined daily dose, skilgreindur sólarhringsskammtur) í hverjum flokki og undirflokki ofangreindra lyfja ( 8 breytur fyrir hvert ár).

Tölur um íbúafjölda einstaklinga 18-35 ára á höfuðborgarsvæðinu (Reykjavík, Kópavogi, Seltjarnarnesi, Garðabæ, Hafnarfirði, Sveitarfélaginu Álftanesi og Mosfellsbæ) voru fengnar á heimasíðu Hagstofu Íslands.

Við tölfræðilega úrvinnslu var notað SPSS útgáfa 24 og RStudio útgáfa 1.1.419. Einföld lýsandi tölfræði var unnin í SPSS og niðurstöður fluttar í Microsoft Excel útgáfu 16.12 par sem gerðar voru töflur og myndir. Í RStudio var gerð Poisson-aðhvarfsgreining til að skoða breytingar milli ára, en í líkaninu er gert ráð fyrir mannfjöldabreytingum. Tölfræðileg marktæknimörk voru sett við p-gildi $<0,05$.

Vísindasiðanefnd sampykkti framkvæmd rannsóknarinnar (VSN-18-007). Persónuvernd gerði ekki athugasemdir við leyfisveitingu nefndarinnar. Einnig fékkst leyfi frá vísindanefnd Heilsugæslu höfuðborgarsvæðisins og Háskóla Íslands, dagsett 8. janúar 2018. 


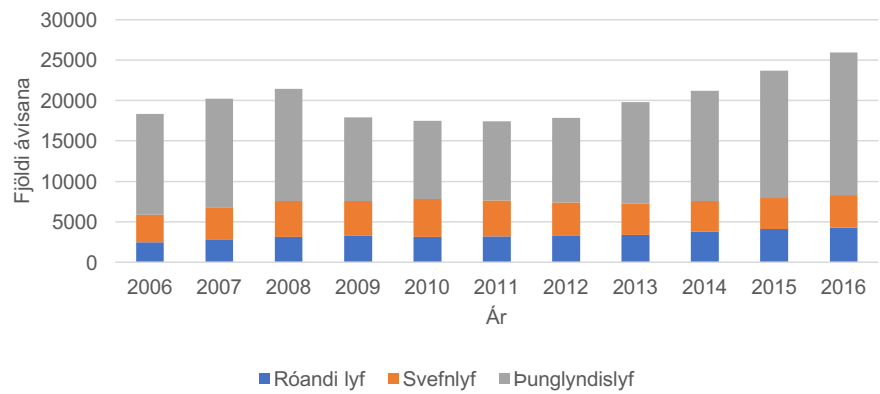

Mynd 1. Fjöldi ávísana róandi lyfja, svefnlyfja og punglyndislyfja til einstaklinga 1835 ára hjá Heilsugæslu höfuðborgarsvæðisins 2006-2016.

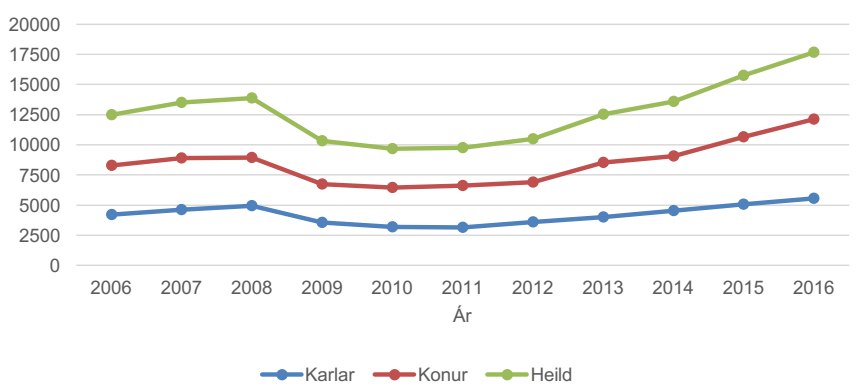

Mynd 2. Punglyndislyf, fjöldi ávísana til einstaklinga 18-35 ára hjá Heilsugæslu höfuðborgarsvæðisins 2006-2016.

\section{Niðurstöður}

Á tímabilinu 2006-2016 fengu tæplega 23.000 manns á aldrinum 18-35 ára ávísað einu eða fleiri lyfjum úr flokki punglyndislyfja, róandi lyfja eða svefnlyfja. Árið 2006 fengu 4005 manns eina eða fleiri ávísanir á ofangreind lyf og árið 2016 hafði peim fjölgað um tæp 66\% og voru pá orðnir 6645. Hluti pessa fólks fékk ávísað lyfi úr fleiri en einum lyfjaflokki. Eldri einstaklingar fengu fleiri ávísanir en peir yngri en mesta aukningin varð á ávísunum til 18 ára einstaklinga, úr 48 í 155, eða um tæp 223\%.

Pegar ávísanir fyrir pessa prjá lyfjaflokka eru skoðaðar kemur í ljós að mesta fjölgunin varð á peim sem fengu ávísað punglyndislyfjum, eða um tæplega 87\% frá 2006-2016. Pá fengu tæplega 75\% fleiri einstaklingar ávísað róandi lyfjum árið 2016 borið saman við árið 2006 (tafla I).

Ekki voru miklar breytingar á hlutfalli karla og kvenna sem fengu ávísað punglyndislyfjum og róandi lyfjum á rannsóknartímabilinu. Konur voru í meirihluta öll árin, tvær á móti einum karli. Á tímabilinu varð breyting á kynjahlutfalli peirra sem fengu ávísað svefnlyfjum í pá átt að pað varð jafnara en pó voru konur alltaf fleiri. Árið 2006 var hlutfallið svipað og fyrir punglyndisog róandi lyf, eða um 66\% konur, en árið 2016 hafði hlutfall karla aukist í tæp 45\% og hlutfall kvenna var komið niður í 55\%. Á mynd 1 og í töflu I sést að langflestar ávísanir voru á punglyndislyf. Frá 2006-2014 voru fleiri ávísanir á svefnlyf en róandi lyf en árin 2015 og 2016 voru ávísanir á róandi lyf orðnar fleiri.

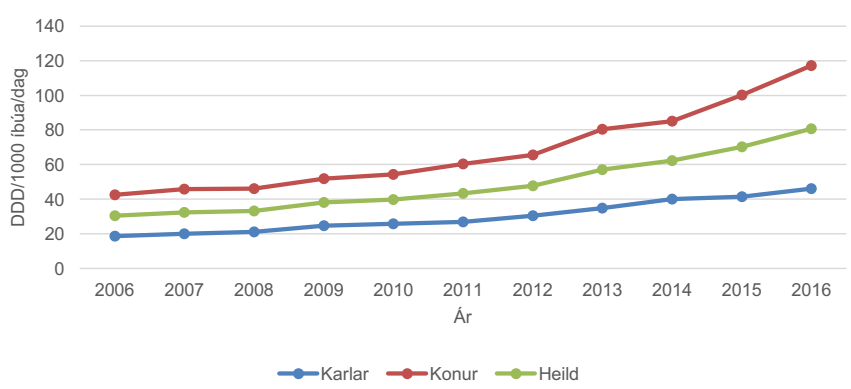

Mynd 3. Sértækir serótónín-endurupptökuhemlar, DDD/1000 íbúa/dag. Einstaklingar 18-35 ára sem fengu ávísað lyfjunum hjá Heilsugæslu höfuðborgarsvæðisins 2006-2016.

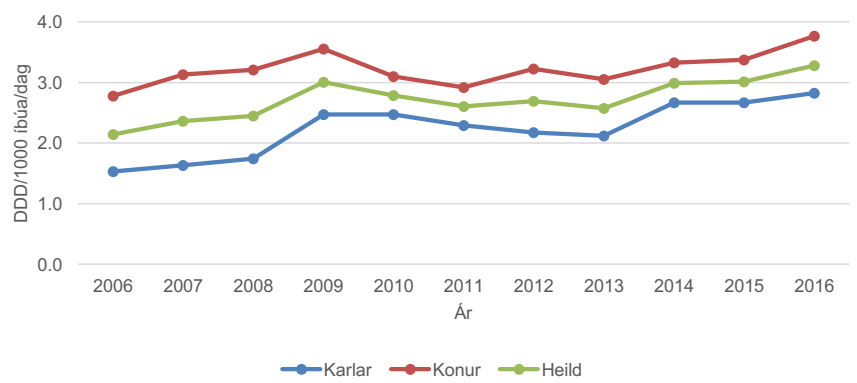

Mynd 4. Róandi og kvíðastillandi lyf, DDD/1000 íbúa/dag. Einstaklingar 18-35 ára sem fengu ávísað lyfjunum hjá Heilsugæslu höfuðborgarsvæðisins 2006-2016.

\section{Dunglyndislyf}

Fjöldi einstaklinga sem fékk ávísað punglyndislyfi tæplega tvöfaldaðist frá 2006-2016 en að meðaltali jókst hann um 6,2\% ( $\mathrm{p}<0,001)$ milli ára og var hlutfallsleg aukning meiri hjá konum. Lyfjaávísanir voru fleiri árið 2016 en árið 2006 en frá 2008-2009 fækkaði peim um meira en 3500 (mynd 2). Ávísuðum dagsskömmtum punglyndislyfja fjölgaði að meðaltali um 10,5\% (p<0,001) milli ára á tímabilinu.

Af undirflokkum punglyndislyfja höfðu sértækir serótónínendurupptökuhemlar (SSRI) langstærsta hlutdeild og var hún frá $81 \%-86 \%$ á tímabilinu (mæld í DDD/1000 íbúa/dag). DDD SSRI-lyfja á hverja 1000 íbúa á dag jukust ár frá ári og árið 2016 hafði orðið tæplega preföldun hjá konum en hjá körlum varð aukningin 146\% (mynd 3).

\section{Róandi lyf og kvíðastillandi lyf}

Fjöldi einstaklinga sem fékk ávísað róandi lyfjum jókst hlutfallslega jafnmikið hjá konum og körlum frá 2006-2016 og að meðaltali fjölgaði peim um 4,9\% ( $<<0,001)$ milli ára. Svipuð fjölgun varð á lyfjaávísunum á tímabilinu. Fjöldi DDD jókst að meðaltali um $3,0 \%(\mathrm{p}<0,001)$ frá ári til árs en frá 2008-2009 jukust peir um 22,7\% $(\mathrm{p}<0,001)$, par af um 12,9\% ( $\mathrm{p}<0,001)$ hjá konum og 39,5\% hjá körlum $(\mathrm{p}<0,001)$ (mynd 4). Af peim körlum sem fengu ávísað róandi lyfjum árið 2009 höfðu 35\% ekki fengið ávísað lyfjunum árið áður. 


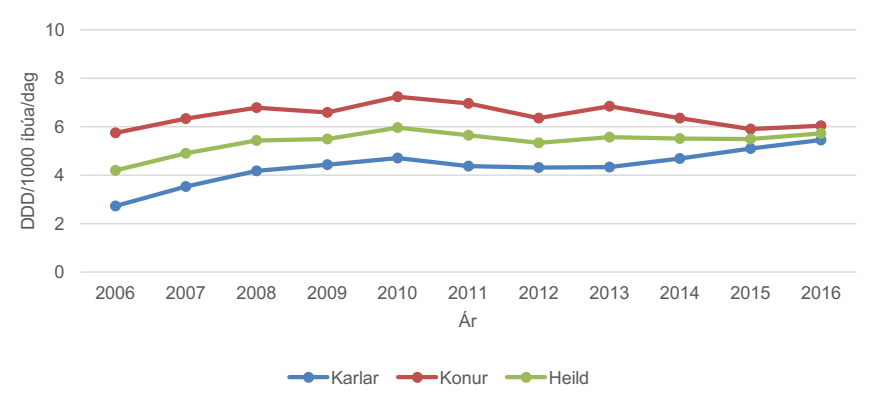

Mynd 5. Svefnlyf og slævandi lyf, DDD/1000 íbúa/dag. Einstaklingar 18-35 ára sem fengu ávísað lyfjunum hjá Heilsugæslu höfuðborgarsvæðisins 2006-2016.

\section{Svefnlyf og slævandi lyf}

Lítil breyting varð á fjölda ávísana og fjölda einstaklinga sem fengu ávísað svefnlyfjum á tímabilinu 2006-2016. Fjöldi DDD jókst hins vegar að meðaltali um 1,6\% ( $\mathrm{p}<0,001)$ frá ári til árs á tímabilinu en í aðdraganda hrunsins frá 2006-2008 var aukningin að meðaltali 13,6\% (p<0,001), par af 7,8\% (p<0,001) hjá konum og 24,4\% hjá körlum $(\mathrm{p}<0,001)$ (mynd 5).

\section{Umræða}

Ávísað magn punglyndislyfja, róandi lyfja og svefnlyfja til einstaklinga á aldrinum 18-35 ára jókst mjög mikið á árunum 2006-2016 hjá $\mathrm{HH}$. Átján ára einstaklingum sem fengu ávísað pessum lyfjum fjölgaði um 223\% á tímabilinu og hjá öllum árgöngum 18-22 ára fjölgaði einstaklingum um meira en $85 \%$. Á árunum kringum hrun sáust áberandi breytingar á ávísunum róandi lyfja og svefnlyfja sem dró svo úr upp úr 2009. Hins vegar varð aukning i ávísunum punglyndislyfja ekki veruleg fyrr en upp úr árinu 2011.

Kynjahlutfall peirra sem fengu ávísað pessum lyfjum er sambærilegt við niðurstöður íslenskrar rannsóknar frá 2016 par sem skoðuð voru tengsl fjölveikinda og algengis ávísana á punglyndislyf og svefnlyf hjá HH á tímabilinu 2009-2012. Par reyndist hlutfallið vera $35,3 \%$ karlar og $64,7 \%$ konur. $^{21}$

Nýleg úttekt Embættis landlæknis sýndi 21,7\% fjölgun notenda punglyndislyfja á árunum 2012-2016, mest hjá aldurshópnum 15-19 ára, eða um $62 \%{ }^{13}$ Petta er í samræmi við okkar niðurstöður sem sýna að á sama tímabili fjölgaði einstaklingum á aldrinum 18-35 ára sem fengu ávísað punglyndislyfjum hjá $\mathrm{HH}$ um 54\%. Árin á undan, frá 2006-2011, virðist aukningin hins vegar hafa verið lítil sem engin. Önnur úttekt Embættis landlæknis sýnir að skammtar punglyndislyfja hafa aukist meira en fjöldi notenda. ${ }^{15}$ Er petta einnig samhljóða okkar niðurstöðum par sem fram kemur tæplega 185\% aukning í ávísuðum skömmtum (DDD) en einstaklingum fjölgaði um $87 \%$ á tímabilinu. Pessar niðurstöður benda til pess að um leið og notendum fjölgar sé stærri skömmtum ávísað, einstaklingar séu lengur á lyfjunum eða hvort tveggja.

Ef próun í fjölda ávísana punglyndislyfja er skoðuð má sjá áberandi fækkun ávísana árið 2009 miðað við árin á undan. Á sama tíma varð aukning í ávísuðu magni. Líkleg ástæða pess að ávís- unum fækkar pó magn aukist er sú að 1. mars 2009 tók gildi ný reglugerð sem breytti greiðslupátttöku sjúkratrygginga pannig að hætt var að miða afgreiðsluhámark punglyndislyfja í flokki SSRI lyfja við 30 daga notkun og var miðað við 100 daga notkun.

Athyglisvert er að bera saman próun ávísana á punglyndislyf, róandi lyf og svefnlyf á tímabilinu rétt í kringum hrunið. Sú staðreynd að ekki sást samskonar aukning á ávísuðu magni punglyndislyfja á tímabilinu eins og róandilyf og svefnlyfja bendir til pess að skammvirkum, fljótvirkum lyfjum hafi verið ávísað í tengslum við erfiðar persónulegar aðstæður í kringum hrunið. Petta verður að teljast nokkuð rökrétt miðað við virkni lyfjanna og gætu pau pví verið lausn á vandamáli sjúklings sem leysa parf hratt og var ef til vill talið tímabundið.

Hins vegar sést á ný nokkuð áberandi aukning í skömmtum punglyndis-, róandi og svefnlyfja á seinni hluta rannsóknartímabilsins, frá árinu 2013. Hvað veldur pessari aukningu er óljóst, til dæmis hvort hana megi rekja til ytri aðstæðna í íslensku samfélagi.

Samanburðarrannsóknir á notkun geðlyfja hafa oftar en ekki sýnt fram á meiri notkun hér á landi en í nágrannalöndunum. Árið 2016 var notkun punglyndislyfja 143\% meiri á Íslandi en í Noregi og 43\% meiri en í Svípjóð. ${ }^{9,11}$ Á sama ári var ávísað 68,4 DDD/1000 íbúa/dag hér á landi miðað við 49,7 í Svípjóð sem kom næst og 14,3 í Danmörku par sem notkunin var minnst. ${ }^{9,18}$ Pá er notkun punglyndislyfja meiri hér á landi en í öllum öðrum OECD-ríkjum. ${ }^{12}$ Hefur pví margoft verið velt upp hver skýring pessa gæti verið. Í grein frá 2016 nefndi páverandi landlæknir skort á samvinnu heilbrigðisstétta, skort á gæðavísum og árangursmati og meingallað fjármögnunarkerfi sem mögulegar skýringar. ${ }^{22}$ Pá hefur skortur á úrræðum oft verið nefndur sem möguleg skýring. Sálfræðipjónusta, sem samkvæmt klínískum leiðbeiningum ætti að vera fyrsta val við meðferð við vægum til meðalmiklum kvíða og punglyndi, er dýr og ekki niðurgreidd til jafns við lyfjameðferð. ${ }^{23}$

Helsti styrkleiki pessarar rannsóknar er stórt rannsóknarpýði en pað voru tæplega 23.000 einstaklingar á aldrinum 18-35 ára sem fengu ávísað einu eða fleiri lyfjum úr ofangreindum flokkum á tímablinu 2006-2016. Fjöldi íbúa höfuðborgarsvæðisins á sama aldri á pessu tímabili var rúmlega 55.000. Gögnin sem notuð voru til úrvinnslu voru fengin úr Sögukerfi HH og tengd lyfjaávísunum lækna. Sambærilegar íslenskar rannsóknir hafa nýtt gögn úr lyfjagagnagrunni Embættis landlæknis, sem á peim árum sem hér voru skoðuð hafði verið gagnrýndur fyrir óáreiðanleika.

Í rannsókninni voru aðeins skoðaðir peir sem sóttu pjónustu $\mathrm{HH}$ og pví endurspeglar hún pá próun sem hefur orðið í heilsugæslu á höfuðborgarsvæðinu á tímabilinu. Hins vegar nær rannsóknarpýðið til um 2/3 allra einstaklinga á Íslandi á pessum aldri á rannsóknartímanum.

\section{Ályktun}

Rannsóknin sýnir marktækar breytingar á ávísunum á róandi lyf og svefnlyf til ungra skjólstæðinga HH í kringum efnahagshrunið 2008. Á sama tíma sást ekki samskonar breyting á ávísunum á 


\section{Pakkir}

punglyndislyf. Hins vegar sést mikil aukning á ávísunum á punglyndislyf á undanförnum árum. Pó að rannsóknin geti ekki sýnt fram á orsakasamband er ekki ólíklegt að breytingar á ávísunum á svefnlyf og róandi lyf tengist aðstæðum tengdum hruninu. Hvort aukning á ávísunum á punglyndislyf undanfarin ár séu með einhverjum hætti seinkomin áhrif hrunsins á ungt fólk á Íslandi er óljóst.
Lilja B. Kristinsdóttir og Jens Á. Reynisson við deild rafrænnar pjónustu hjá $\mathrm{HH}$ fá pakkir fyrir aðstoð við að setja upp gagnabankann sem rannsóknin var unnin upp úr. Sigrún Helga Lund og Sigrún Ýr Eyjólfsdóttir fá pakkir fyrir ráðleggingar og aðstoð við tölfræðilega úrvinnslu. Arna Pórdís Árnadóttir, fulltrúi á Próunarmiðstöð íslenskrar heilsugæslu, fær pakkir fyrir aðstoð við ritvinnslu.

Greinin barst til blaðsins 20. mars 2019, sampykkt til birtingar 21. ágúst 2019.

\section{Heimildir}

1. Skráð atvinnuleysi eftir landsvæðum og kyni 1957-2015. Hagstofa Íslands. px.hagstofa.is/pxis/sq/6029f24b-a5d07703-9b4a-eb83b08281cf - mars 2018 .

2. Heimili í fjárhagsvandræðum eftir aldri, 2004-2012. Hagstofa Íslands. px.hagstofa.is/pxis/sq/24592a71-9a11-4c20-a93f-e9687033965c - mars 2018

3. Karanikolos M, Mladovsky P, Cylus J, Thomson S, Basu S, Stuckler D, et al. Financial crisis, austerity, and health in Europe. Lancet 2013; 381: 1323-31.

4. Guðjónsdóttir GR, Kristjánsson M, Ólafsson Ö, Arnar DO, Getz L, Sigurðsson JÁ, et al. Immediate surge in female visits to the cardiac emergency department following the economic collapse in Iceland: an observational study Emerg Med J 2012; 29: 694-8.

5. McKee M, Karanikolos M, Belcher P, Stuckler D. Austerity: a failed experiment on the people of Europe. Clin Med (Lond) 2012;1 2:3 46-50.

6. Reeves A, McKee M, Stuckler D. Economic suicides in the Great Recession in Europe and North America. Br J Psychiatry 2014; 205: 246-7.

7. Ásgeirsdóttir HG, Ásgeirsdóttir TL, Nyberg $\mathrm{U}$, porsteinsdóttir PK, Mogensen B, Matthíasson P, et al. Suicide attempts and self-harm during a dramatic national economic transition: a population-based study in Iceland. Eur J Public Health 2017: 27: 339-45.

8. Lyfjanotkun Íslendinga og lyfjagagnagrunnur landlæknis Embætti landlæknis, 2017. landlaeknir.is/um-embaettid/ frettir/frett/item32339/lyfjanotkun-islendinga-og-lyfjagagnagrunnur-landlaeknis - mars 2018.
9. Nordic Medico-Statistical Committee (NOMESCO). Health Statistics for the Nordic Countries 2017. 1. útg. Kaupmannahöfn: 2017.

10. Tauga- og geðlyfjanotkun á Íslandi. Embætti landlæknis, 2016. landlaeknir.is/um-embaettid/frettir/frett/item28980/ tauga-og-gedlyfjanotkun-i-oecd-rikjum-mest-a-islandi mars 2018 .

11. Sales of antidepressants (ATC-group N06A), 2004-2015 Nordic Medico-Statistical Committee (NOMESCO) - mars 2018.

12. OECD. Health at a Glance 2017: OECD Indicators. 1. útg. OECD publishing; París 2017.

13. Mikil aukning 1 ávísunum punglyndislyfja á undanförnum árum. Embætti landlæknis, 2017. landlaeknir. is/um-embaettid/frettir/frett/item31934/mikil-aukning-i-avisunum-thunglyndislyfja-a-undanfornum-arum - mars 2018

14. Embætti landlæknis. Punglyndislyf á Íslandi. Læknablaðið 2014; 100: 355

15. Mikil aukning í ávísunum punglyndislyfja á ungmenn hér á landi. Embætti landlæknis, 2017. landlaeknir. is/um-embaettid/frettir/frett/item32772/mikil-aukning-i-avisunum-thunglyndislyfja-a-ungmenni-a-islandi - mars 2018.
16. Sales of anxiolytics (ATC-group N05B), 2004-2015. Nordic Medico-Statistical Committee (NOMESCO) - mars 2018.

17. Ávísunum á tauga- og geðlyf á Íslandi hefur fjölgað frá 2003 til 2013. Embætti landlæknis, 2014. landlaeknir.is/ um-embaettid/frettir/frett/item25254 - mars 2018

18. Sales of hypnotics and sedatives (ATC-group N05C), 20042015. Nordic Medico-Statistical Committee (NOMESCO - mars 2018

19. Svefnlyfjanotkun á Íslandi. Embætti landlæknis, 2015. landlaeknir is/um-embaettid/frettir/frett/item27085/svefnlyfjanotkun-a-islandi - mars 2018

20. Stewart R, Besset A, Bebbington P, Brugha T, Lindesay J, Jenkins R, et al. Insomnia comorbidity and impact and hypnotic use by age group in a national survey population aged 16 to 74 years. Sleep 2006; 29: 1391-7.

21. Linnet K, Guðmundsson LS, Birgisdóttir FG, Sigurðsson EL, Jóhannsson M, Tómasdóttir MÓ, et al. Multimorbidity and use of hypnotic and anxiolytic drugs: cross-sectional and follow-up study in primary healthcare in Iceland. BMC Fam Pract 2016; 17: 1-10.

22. Jakobsson B. Lyfjanotkun Íslendinga. Talnabrunnur 2016 nóvember - desember: 1-2.

23. Depression in adults: recognition and management (NICE guideline CG91). National Institute for Health and Care Excellence (NICE), 2009. nice.org.uk/guidance/cg90/ chapter/1-Guidance\#care-of-all-people-with-depression mars 2019. 


\section{Antidepressants, anxiolytics and hypnotics prescribed to young adults before and after an economic crisis in Iceland}

- A cross-sectional study at the Primary Health Care of Reykjavik capital area

\author{
Árni Arnarson ${ }^{1}$ \\ Jón Steinar Jónsson ${ }^{1,2,3}$ \\ Margrét Ólafía Tómasdóttir ${ }^{1,2}$ \\ Emil Lárus Sigurðsson ${ }^{1,2,3}$
}

Background: According to research findings, the financial crisis hitting Iceland in the autumn of 2008 caused both economic and health-related effects on the Icelandic population. It has been well known that the Icelandic population uses more antidepressants, anxiolytics and hypnotics compared to other Nordic countries. The aim of this research was to study the trend in prescription for these drugs by the Primary Health Care of Reykjavik capital area to young adults, during the years prior to and following the crisis.

Method: In this cross-sectional study, data were gathered on all medical prescriptions of antidepressants, anxiolytics and hypnotics, prescribed by the Primary Health Care of Reykjavik capital area to people aged 18-35, during 2006-2016. While Reykjavík capital residents in the specified age group were approximately 55 thousand during the research period, this study included data on approximately 23 thousand individuals, received from the Icelandic electronical medical record system "Saga" used by the Primary Health Care. Results: Research results demonstrate a significant average annual increase of prescribed defined daily doses (DDD) for all three medication categories during the research period; $3 \%(p<0,001)$ for anxiolytics, $1.6 \%(p<0,001)$ for hypnotics and $10.5 \%(p<0,001)$ for antidepressants. Between 2008-2009, prescribed daily doses of anxiolytics increased by $22.7 \%(p<0,001)$, where a $12.9 \%(p<0,001)$ increase was seen for women and $39.5 \%(p<0,001)$ increase for men. Of those men who were prescribed anxiolytics in 2009 , 35\% had no history of such prescriptions the previous year. From 20062008 an average annual increase of $13.6 \%(p<0,001)$ was seen in prescribed daily doses of hypnotics, whereof $24.4 \%(p<0,001)$ increase was seen for men and $7.8 \%(p<0,001)$ for women.

Conclusions: This study demonstrates a significant increase in prescribed amount of hypnotics and anxiolytics during the years prior and after the economic crisis, with more prominent results amongst men compared to women. This trend was however not observed for antidepressants, which could suggest an overall tendency towards short- and fast acting drug prescriptions as a treatment for challenging difficult personal circumstances during the economic crisis in Iceland.

Key words: Drug prescriptions, anxiety, depression, sleep disturbances, economical crisis. 